\title{
Microarray analysis of insulin-regulated gene expression in the liver: The use of transgenic mice co-expressing insulin-siRNA and human IDE as an animal model
}

\author{
SEUNGWAN JEE ${ }^{1}$, DAEYOUN HWANG ${ }^{1}$, SUJIN SEO ${ }^{1}$, YONGKYU KIM ${ }^{1}$, CHUELKYU KIM ${ }^{1}$, BYUNGGUK KIM ${ }^{1}$, \\ SUNBO SHIM $^{1}$, SUHAE LEE ${ }^{1}$, JISOON SIN ${ }^{1}$, CHANGJUN BAE ${ }^{1}$, BYOUNGCHUN LEE ${ }^{1}$, MEEKYUNG JANG ${ }^{1}$, \\ MINSUN KIM ${ }^{1}$, SUYOUN YIM ${ }^{1}$, INSURK JANG ${ }^{2}$, JUNGSIK CHO ${ }^{1}$ and KABRYONG CHAE ${ }^{1}$ \\ ${ }^{1}$ Laboratory Animal Resources Team, National Institute of Toxicological Research, Korea FDA, Seoul 122-704; \\ ${ }^{2}$ Department of Animal Science and Biotechnology, RAIRC, Jinju National University, Jinju 660-758, Korea
}

Received January 29, 2007; Accepted March 8, 2007

\begin{abstract}
To characterize the changes in global gene expression in the livers of $\mathrm{H} 1 / \mathrm{siRNA}_{\text {insulin }}-\mathrm{CMV} / \mathrm{hIDE}$ transgenic $(\mathrm{Tg})$ mice in response to the reduced bioavailability of insulin, total RNA extracted from the livers of 20-weekold $\mathrm{Tg}$ and non-Tg mice was converted to cDNA, labeled with biotin and hybridized to oligonucleotide microarrays. The microarray results were confirmed by a real-time reverse transcription-polymerase chain reaction. Two hundred and fifty-one and 73 genes were up- and down-regulated, respectively by insulin in $\mathrm{H} 1 / \mathrm{siRNA}_{\text {insulin }}-\mathrm{CMV} / \mathrm{hIDE} \mathrm{Tg}$ mice compared to the controls. Genes encoding for physiological processes, extracellular defense response and response to biotic stimuli were significantly over-represented in the up-regulated group. Among the down-regulated transcripts, those encoding for extracellular matrix proteins were dramatically over-represented, followed by those related to monooxygenase and oxidoreductase activities. The major genes in the up-regulated categories included Egr1, Saa2, Atf3, DNAJB1 and cCL2, whereas those in the downregulated categories were Cyp17a1, Adn, Gadd45g, Eno3 and Moxd1. These results indicate that the microarray analysis identifies several gene functional groups and individual genes that respond to a sustained reduction in the insulin levels in the livers of $\mathrm{Tg}$ mice. These results also suggest that microarray testing is a useful tool for the better understanding of insulin-regulated diabetes-related diseases.
\end{abstract}

Correspondence to: Dr Dae Youn Hwang, Laboratory Animal Resources Team, National Institute of Toxicological Research, Korea FDA, 5 Nokbun-dong Eunpyung-ku, Seoul 122-704, Korea E-mail: dyhwang@kfda.go.kr

Key words: microarray, siRNA, IDE, insulin, diabetes model

\section{Introduction}

Insulin is a very crucial biomolecule, which rapidly decreases the blood glucose level and inhibits the production of endogenous glucose. This protein also exerts its potent effects on hepatic glucose fluxes via direct and indirect mechanisms (1-4). The direct effects can be further divided into 'acute' insulin actions, which lead to a rapid decrease in glucose production (5-7), and 'chronic' insulin actions, which regulate the gene expression of key gluconeogenic enzymes (8-10). Studies on dogs have indicated that the acute and direct effects of insulin on the liver mainly inhibit hepatic glycogenolysis (11). The indirect effects of insulin on the output of hepatic glucose include the suppression of lipolysis, inhibition of glucagon secretion and activation of hypothalamic descending pathways $(12,13)$.

H1/siRNA insulin $-\mathrm{CMV} / \mathrm{hIDE} \mathrm{Tg}$ mice (TG9385) had the chromosome integrated dual-recombinant expression system, containing insulin siRNA and human IDE under the control of the $H 1 C M V$ promoters, respectively (14-16). This system was first established in H1/siRNAEGFP-CAG/HcRed1 Tg mice co-expressing an enhanced red fluorescent protein and a suppressed green fluorescent protein (17). In the dual expression system, small interfering RNA or double-strand RNA (dsRNA)-based gene silencing is a highly conserved mechanism for sequence-specific post-transcriptional gene silencing between various species $(18,19)$. This technique has been used in the nematode Caenorhabditis elegans to suppress gene expression by an injection of a double-strand mixture into adult animals (20). However, this method has a critical limitation in that the transfected synthetic siRNA works for only a few days in mammalian cells. This problem can be overcome by a vector-based technique for the synthesis of siRNA driven by the RNA polymerase III promoter (21-23). However, there are no reports as to whether the transgenebased siRNA system can suppress the expression of the insulin gene in adult mice.

In $\mathrm{H} 1 /$ siRNA $_{\text {insulin }}-\mathrm{CMV} / \mathrm{hIDE} \mathrm{Tg}$ mice, the highest insulin siRNA and hIDE expression levels were observed in the muscle, followed by the lung, brain, heart, liver, kidney and 
intestine. Furthermore, the level and activity of hIDE mature proteins $(110-\mathrm{kDa})$ were significantly higher in the liver, which is the primary target tissue for insulin clearance. These Tg mice also showed significant impairment of glucose tolerance during the course of an IPGTT. In particular, the 20-week-old Tg mice showed a greater impairment of glucose tolerance than their non-Tg counterparts, with a higher difference being observed in the male mice. The serum insulin level was significantly lower in the H1/siRNA insulin $^{-}$ $\mathrm{CMV} / \mathrm{hIDE} \mathrm{Tg}$ than non-Tg mice $(14,16)$.

In this study, we characterized the changes in global gene expression in the livers of $\mathrm{H} 1 /$ siRNA $_{\text {insulin }}-\mathrm{CMV} / \mathrm{hIDE} \mathrm{Tg}$ mice in response to reduced bioavailability of insulin.

\section{Materials and methods}

H1/siRNA $A_{\text {insulin }}-C M V / h I D E$ transgenic mice. The $\mathrm{H} 1 /$ siRNA $_{\text {insulin }}-\mathrm{CMV} / \mathrm{hIDE} \mathrm{Tg}$ mice used in this study were developed in our laboratory by the microinjection of the male pronucleus of fertilized embryos, which were obtained by the crossing of C57BL/6 (female) mice with DBA2 (male) mice during 2005. The injected egg was then transferred into the oviducts of a pseudopregnant ICR recipient female. The transgene was identified by DNA-PCR analysis of the genomic DNA isolated from the tails of the 4-week-old founder mice. The H1/siRNA insulin $-\mathrm{CMV} / \mathrm{hIDE}$ DNA was synthesized using the sense and antisense primers, 5'-GGT TTT CCC AGT CAC GAC-3 and 5'-GAG TTA GCT CAC YCA TAG GC-3, respectively, with a complementary H1/ siRNA $_{\text {insulin }}-\mathrm{CMV} / \mathrm{hIDE}$ vector, ranging from 359-376 and 663-683 nucleotides, as the DNA template. After 25 cycles of amplification, the level of the PCR product (324-bp) was quantified on $1 \%$ agarose gels using a Kodak electrophoresis documentation and analysis system 120. A total of ten 22week-old mice, five $\mathrm{Tg}$ and five non-Tg were used in this study.

All the mice were kept in an accredited Korea FDA animal facility in accordance with the AAALAC International Animal Care policies (Accredited Unit-Korea Food and Drug Administration, unit no. 000996). The mice were given a standard irradiated chow diet (Purina Mills Inc.) ad libitum, and maintained in a specified pathogen-free state under a strict light cycle (light on at 06:00 h and off at 18:00 h). All pedigrees were hemizygous for their transgene.

RNA isolation. The livers from 22-week-old Tg mice and their non-Tg littermates were used for isolation of total RNA using RNAzol (Tel-Test Inc., CS104) according to the manufacturer's instructions. The frozen tissues were chopped with scissors and homogenized in RNAzol B solution using a glass-Teflon homogenizer. Chloroform, $0.2 \mathrm{vol}$, was added to the mixture, shaken vigorously for $15 \mathrm{sec}$ and then incubated on ice for $5 \mathrm{~min}$. After incubation on ice, the homogenate was separated into two phases by centrifugation at $12,000 \mathrm{rpm}$ for $15 \mathrm{~min}$. The aqueous phase was transferred to a fresh tube and precipitated with an equal volume of isopropanol. The RNA pellet was suspended in DEPC (diethylpyrocarbonate)-treated $\mathrm{dH}_{2} \mathrm{O}$ and purified using a QIAquick purification kit (Qiagen, CA). The integrity of the $18 \mathrm{~S} / 28 \mathrm{~S}$ rRNA was analyzed using a Bioanalyzer 2100 (Agilent), with the RNA quality checked by the ratio of the absorbance at $260 \mathrm{~nm}$ to that at $280 \mathrm{~nm}$ using a biophotometer (Eppendorf, Germany).

cRNA synthesis and labeling. cRNA synthesis and labeling were performed using a Chemiluminescent RT-IVT labeling kit (Applied Biosystems, CA) according to the manufacturer's instructions. Six individual samples were submitted in randomly assigned pairs representing tissues from non-Tg and $\mathrm{Tg}$ mice. Three micrograms of total RNA was used to synthesize cDNA. Total RNA was incubated with T7oligo(dT) primer in nuclease-free water for $10 \mathrm{~min}$ at $70^{\circ} \mathrm{C}$. The resulting solution was continuously incubated for $2 \mathrm{~h}$ at $42^{\circ} \mathrm{C}$ in a reaction mixture containing RNase inhibitor, $10 \mathrm{X}$ 1 st strand buffer mix and reverse transcriptase. Doublestrand cDNA was synthesized for $2 \mathrm{~h}$ at $16^{\circ} \mathrm{C}$ in a reaction mixture containing nuclease-free water, $5 \mathrm{X}$ 2nd strand buffer and 2nd strand enzyme, and then purified using a purification column. Finally, the biotinylated cRNA was generated from the cDNA using a BioArray cRNA high yield RNA transcript kit containing purified double-strand cDNA, 5X IVT buffer mix, DIG-UTP and IVT enzyme mix.

Oligonucleotide array expression analysis. Insulin-regulated gene expression analysis in the liver was conducted using the Mouse Genome Survey microarray (Applied Biosystems, CA) containing oligonucleotide probes for 33,315 genes. The cRNA was fragmented in $5 \mathrm{X}$ fragmentation buffer (200 mM Tris-acetate, $\mathrm{pH} 8.1,500 \mathrm{mM}$ KOAc and $150 \mathrm{mM}$ $\mathrm{MgOAc}$ ) for $30 \mathrm{~min}$ at $60^{\circ} \mathrm{C}$ prior to chip hybridization. Fifteen micrograms of fragmented cRNA was then added to the hybridization cocktail $(0.05 \mu \mathrm{g} / \mu \mathrm{l}$ fragmented cRNA, $50 \mathrm{pM}$ control oligonucleotide, $0.1 \mathrm{mg} / \mathrm{ml}$ herring sperm DNA, $0.5 \mathrm{mg} / \mathrm{ml}$ acetylated BSA, $100 \mathrm{mM}$ MES, $1 \mathrm{M} \mathrm{Na}^{+}$, $20 \mathrm{mM}$ EDTA and $0.01 \%$ Tween-20). Each sample was hybridized to a separate oligonucleotide array for $16 \mathrm{~h}$ at $55^{\circ} \mathrm{C}$ in the GeneChip hybridization oven 640 . After hybridization, the solution was removed and the slides washed twice with $2 \mathrm{X} \mathrm{SSC}$ containing $0.1 \%$ SDS for $5 \mathrm{~min}$ at $42^{\circ} \mathrm{C}$. The slides were incubated for $20 \mathrm{~min}$ with the anti-Dig-AP in CL blocking buffer, and then developed using the chemiluminescence substrate. Thereafter, the hybridized arrays were scanned using an AB 1700 analyzer. Scanning and basic analysis were performed using the GenPlex software release 1.0 (Istech Inc., Korea).

Real-time PCR analysis of representative genes. The expression of the representative genes was examined using real-time PCR analysis with $5 \mu \mathrm{g}$ of the total RNA from each tissue. For reverse transcription, $500 \mathrm{ng}$ of the oligo-dT primer [Gibco BRL (18418-012)] was annealed for $10 \mathrm{~min}$ at $70^{\circ} \mathrm{C}$. The complementary DNA, which served as the template for further amplification, was synthesized by the addition of dATP, dCTP, dGTP, dTTP and 200 units of reverse transcriptase. After reverse transcription, real-time PCR analysis was carried out in triplicate for each mixture, with the addition of the synthesized cDNA to TaqMan Universal master mix and CYP AdB product (mixture of sense, antisense, and FAM primer). PCR for glyceraldehyde3-phosphate dehydrogenase (GAPDH), as an endogenous 


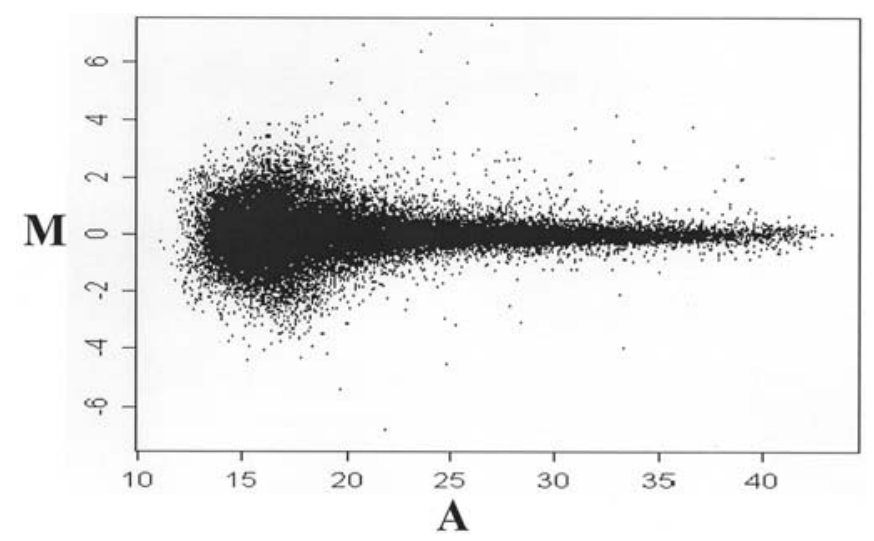

Figure 1. MA plots of cDNA microarray hybridization. Gene expression signals of $\mathrm{H} 1 / \mathrm{siRNA}_{\text {insulin }}-\mathrm{CMV} / \mathrm{hIDE} \mathrm{Tg}$ and non-Tg mice. Each point represents the average expression value for the same gene from the non- $\mathrm{Tg}$ and $\mathrm{Tg}$ mice. MA plots were used to represent the $\mathrm{R}$ and $\mathrm{G}$ data, where $M=\log 2 \mathrm{R} / \mathrm{G}$ and $\mathrm{A}=\log 2(\mathrm{RxG}) . \mathrm{M}$, expression ratio; $\mathrm{A}$, the false color image; $\mathrm{G}$, the stronger control sample hybridization (Cy3); and $\mathrm{R}$, the stronger transgenic sample hybridization (Cy5).

control, was performed simultaneously, with the exception of the rodent GAPDH control reagent (AB4308313). TaqMan probes have two fluorescent dyes, one at the 5'-terminal (Reporter, R) to displace the strand, and the other at the 3'terminal (Quencher, Q) to block the extension. The reaction mixture was then subjected to amplification in the following sequence: 1 cycle at $50^{\circ} \mathrm{C}$ for $2 \mathrm{~min}$ (annealing stage), 1 cycle at $95^{\circ} \mathrm{C}$ for $10 \mathrm{~min}$ (denaturation stage), 40 cycles at $95^{\circ} \mathrm{C}$ for $15 \mathrm{sec}$ and at $60^{\circ} \mathrm{C}$ for $2 \mathrm{~min}$ (extension stage). In all cases, an initial denaturation was carried out at $95^{\circ} \mathrm{C}$ for $5 \mathrm{~min}$ to monitor the decrease in the formation of a primer-dimer complex under these PCR conditions. The ABI-SDS was programmed to take $\mathrm{R}$ and $\mathrm{Q}$ fluorescent dye readings after each cycle at a temperature several degrees $\left(60^{\circ} \mathrm{C}\right)$ lower than the melting temperature of the target amplicon; this step was undertaken to avoid, or at least minimize, any potential contribution to the overall fluorescent dye signals due to primer-dimer formation. A calibration curve was constructed by plotting the R/Q ratio against the amounts of each cDNA synthesized, based on the RNA isolated from the livers of both the $\mathrm{Tg}$ and non-Tg mice, with the latter used as the control.
Statistical analysis. Testing for significance was performed using a one-way ANOVA test of variance (SPSS for Windows, release 10.10, standard version, Chicago, IL). All values were represented as the mean \pm standard deviation (SD), with the mean difference between dietary treatments evaluated at $\mathrm{P}<0.05$.

\section{Results}

Image of the gene expression profile on cDNA microarray. A microarray analysis plot summary of the microarray gene expression data represented on the Mouse Genome Survey microarray $(33,315)$ is shown in Fig. 1 . The location of average gene expression values along the first diagonal showed a non-systematic bias between the non- $\mathrm{Tg}$ and $\mathrm{Tg}$ groups. A higher variance was observed at lower than higher expression levels. A fairly considerable number of genes were also expressed at elevated or reduced levels in the $\mathrm{Tg}$ compared to the non-Tg livers (Fig. 1), although the expression levels of most genes were different between the non- $\mathrm{Tg}$ and $\mathrm{Tg}$ livers. Based on the arbitrary difference in the 2-fold change, 152 genes were revealed to be up-regulated and 73 genes down-regulated in the Tg compared to the nonTg livers.

Ontology categories of insulin-regulated gene expression. To analyze the ontology classification of the insulin-regulated gene expression in the livers of $\mathrm{Tg}$ mice, gene lists were categorized into functional clustering according to the Gene ontology classification using the OntoExpress on-line software; the results are presented in Tables I and II. OntoExpress identified 9 GO categories showing significantly elevated expression in the list of up-regulated transcripts (Table I). As presented in Table I, the largest number of transcripts turned out to be the proteins mainly associated with physiological processes, the extracellular defense response and biotic stimulus. From the list of down-regulated transcripts, OntoExpress identified 5 markedly overexpressed GO categories (Table II). In this group, the transcripts of those genes located on extracellular matrix were especially highly expressed, followed by those involved in monooxygenase and oxidoreductase activities. These results suggest that insulin can regulate the expression of genes

Table I. Gene ontology categories significantly $(\mathrm{p}<0.05)$ over-represented among the 152 gene transcripts up-regulated in the livers of $\mathrm{H} 1 / \mathrm{siRNA}_{\text {insulin }}-\mathrm{CMV} / \mathrm{hIDE} \mathrm{Tg}$ mice.

\begin{tabular}{lccl}
\hline P-value & Number of transcripts & Percent & \multicolumn{1}{c}{ GO category } \\
\hline 0.0004 & 99 & 39.44 & Physiological processes \\
0.0363 & 35 & 13.94 & Extracellular \\
0.0006 & 15 & 5.97 & Defense response \\
0.0017 & 15 & 5.97 & Response to biotic stimulus \\
0.0018 & 12 & 4.78 & Immune response \\
0.0014 & 9 & 3.58 & Response to pest/pathogen/parasite \\
0.0402 & 5 & 1.99 & Lipid binding \\
0.0446 & 3 & 1.19 & Lipid transporter activity \\
0.0327 & 3 & 1.19 & Protein tyrosine/serine/threonine phosphatase
\end{tabular}


Table II. Gene ontology categories significantly $(\mathrm{p}<0.05)$ over-represented among the 73 gene transcripts down-regulated in the livers of H1/siRNA insulin $-\mathrm{CMV} / \mathrm{hIDE} \mathrm{Tg}$ mice.

\begin{tabular}{lcll}
\hline P-value & Number of transcripts & Percent & \multicolumn{1}{c}{ GO category } \\
\hline 0.0405 & 5 & 6.84 & Extracellular matrix \\
0.0209 & 4 & 5.48 & Monooxygenase activity \\
0.0494 & 3 & 4.11 & Oxidoreductase activity \\
0.0395 & 2 & 2.74 & Oxidoreductase activity miscellaneous \\
0.0408 & 2 & 2.74 & Non-G-protein-coupled 7TM receptor \\
\hline
\end{tabular}

Table III. Genes with the highest fold increase among those (152) up-regulated in the livers of H1/siRNA insulin $^{-C M V / h I D E ~ T g ~}$ mice.

\begin{tabular}{|c|c|c|c|}
\hline Name & GeneBank ID & Fold increase & Description \\
\hline Egr1 & M19643 & 9.66 & Nucleic acid binding; transcription factor activity \\
\hline Saa2 & U60438 & 8.20 & Lipid transporter activity; protein binding \\
\hline Atf3 & ВC019946 & 7.84 & DNA binding; transcriptional repressor activity \\
\hline Saa2 & U60438 & 7.32 & Lipid transporter activity; protein binding \\
\hline Dnajb-1 & AB028272 & 6.54 & Heat shock protein binding; unfolded protein binding \\
\hline Tff3 & ВC011042 & 5.90 & - \\
\hline Copeb & AY027436 & 5.66 & Nucleic acid binding; zinc ion binding \\
\hline Gadd45a & L28177 & 5.66 & Protein binding \\
\hline $\mathrm{Ccl} 2$ & M19681 & 5.48 & G-protein-coupled receptor binding; cytokine activity \\
\hline Cxcl-IO & AF227743 & 5.42 & Cytokine activity; chemokine activity \\
\hline Nr4a1 & J04113 & 5.36 & Transcription factor activity; receptor activity \\
\hline Lamb3 & AK078970 & 5.28 & Structural molecule activity; protein binding \\
\hline Slpi & AF002719 & 5.26 & Endopeptidase inhibitor activity \\
\hline ler5 & AF079527 & 5.20 & - \\
\hline Maff & BC022952 & 5.18 & DNA binding \\
\hline Orm2 & M17376 & 5.12 & Transporter activity; binding \\
\hline Trib1 & AF358866 & 5.12 & Nucleotide binding; protein kinase activity \\
\hline $\operatorname{Sh} 2 \mathrm{~d} 2 \mathrm{a}$ & AK037818 & 4.92 & $\mathrm{SH} 3 / \mathrm{SH} 2$ adaptor activity \\
\hline Zfp112 & AF167319 & 4.76 & Nucleic acid binding \\
\hline Hoxa5 & M36604 & 4.64 & DNA binding; transcription factor activity \\
\hline Mt1 & AK011040 & 4.62 & Copper ion binding; zinc ion binding; metal ion binding \\
\hline ler3 & AK051003 & 4.50 & - \\
\hline Myc & L00039 & 4.48 & DNA binding; transcription factor activity \\
\hline Сyp2b13; Cyp2b9 & M21855 & 4.48 & Monooxygenase activity; iron ion binding \\
\hline Rasd-1 & AF009246 & 4.24 & Nucleotide binding; GTP binding \\
\hline Dusp6 & AK088468 & 4.22 & Phosphoprotein phosphatase activity \\
\hline LOC277830 & ВC013476 & 4.12 & Monooxygenase activity; oxidoreductase activity \\
\hline Hmoxl & X13356 & 4.10 & Heme oxygenase (decyclizing) activity \\
\hline S100a9 & M83219 & 4.08 & Calcium ion binding \\
\hline
\end{tabular}

related to physiological processes, the xenobiotic defense response, extracellular matrix and monooxygenase activity in the livers of $\mathrm{Tg}$ mice.

Genes with the highest expression levels of up-regulation and down-regulation. In order to characterize the genes showing the highest overexpression, those with at least a 4-fold increase were selected from the 152 up-regulated and 75 down-regulated genes. As shown in Table III, the highest increase in transcripts showed Egr1 (9.66-fold) to be responsible for the transcription factor activity, followed by Saa2, Atf3, Dnajb1 and Tff3. The various transcriptional factors and transporters were especially significantly elevated by the regulation of insulin in the livers of $\mathrm{Tg}$ mice. Also, 20 genes with the highest fold decreases were significantly overexpressed (Table IV). Of these genes, transcripts of cytochrome family coding genes (Cyp17a1 and Cyp2c) were most dramatically decreased, followed by those associated with proteolysis, regulation of the cell cycle, glycolysis and oxidoreductase activity. These results indicate that insulin 
Table IV. Genes with the highest fold increase among those (73) down-regulated in the livers of H1/siRNA insulin $\mathrm{CMV}_{\mathrm{hIDE}}$ Tg mice.

\begin{tabular}{llll}
\hline Name & GeneBank ID & Fold increase & Description \\
\hline Cyp17a1 & M64863 & 5.96 & Electron transport; hormone biosynthesis \\
Adn & M13386 & 5.28 & Proteolysis; immune response \\
Gadd45g & AF055638 & 5.04 & Regulation of progression through cell cycle \\
Eno3 & M20745 & 4.52 & Glycolysis \\
Cyp2c70 & BC022151 & 4.20 & Oxidoreductase activity \\
Stomll & AK045820 & 3.82 & - \\
Moxd1 & AB041606 & 3.74 & Catecholamine metabolism \\
Sertad3 & AF317202 & 3.74 & Transcription \\
Cck & M11739 & 3.72 & Peuron migration; axonogenesis \\
Vrk2 & AF513620 & 3.64 & Electron transport; retinoic acid metabolism \\
Cyp26a1 & AF115769 & 3.48 & Signal transduction \\
Sntb2 & AK010705 & 3.40 & Biological process unknown \\
Olfr872 & AY318050 & 3.22 & Signal transduction \\
Np1 & AK088859 & 3.18 & \\
Fzd8 & U43321 & 3.16 & Protein amino acid phosphorylation \\
Btbd14a & AK043047 & 3.16 & Branching morphogenesis; transcription \\
Pdk3 & AK075879 & 3.16 & Dopamine receptor signaling pathway \\
Foxa2 & X74937 & 3.10 & Signal transduction \\
Drd-lip & AK003400 & 3.02 & \\
Fzd8 & U43321 & 3.00 & \\
\hline
\end{tabular}

Table V. Comparison of the expression ratios of selected genes from the livers of H1/siRNA insulin $^{-C M V / h I D E ~ T g ~ a n d ~ n o n-T g ~}$ mice, as determined by real-time PCR and microarray analysis.

\begin{tabular}{llcr}
\hline Name & GeneBank ID & \multicolumn{2}{c}{ TG/WT ratio } \\
\cline { 3 - 4 } & & Real-time PCR & Microarray \\
\hline Apolipoprotein A & M64249 & 3.66 & 3.62 \\
Defensin-related cryptdin 4 & AF178040 & 4.31 & 2.46 \\
Fatty acid binding protein 4 & BC018558 & 1.60 & 2.06 \\
Cytochrome P450 family 17 & M64863 & -4.11 & -5.96 \\
Stearoyl-coenzyme A desaturase 1 & BC007474 & -3.73 & -2.62 \\
Nephronectin & BC068308 & -2.22 & -2.18 \\
Cytochrome P450 family 2 & BC022151 & -3.12 & -4.10 \\
\hline
\end{tabular}

can be closely involved in the regulation of genes for transcription factors, transporters, cytochrome and glycolysis under the condition of a low insulin level.

Comparison of expression ratios of selected genes. In an attempt to compare the expression ratios of several genes from the liver, the expression levels of selected genes were examined by real-time PCR. Seven of the up- and downregulated genes judged from GeneChip data were selected, and also analyzed by real-time PCR. Table V shows the fold changes in each gene expression in the $\mathrm{H} 1 / \mathrm{siRNA}_{\text {insulin }}{ }^{-}$ $\mathrm{CMV} / \mathrm{hIDE} \mathrm{Tg}$ mice compared to those in the control mice when analyzed by the GeneChip and real-time PCR. The changes in these levels of gene expression were similar in direction and magnitude between the two techniques. These results suggested that the expression ratios from the microarray in selected genes were very similar to those from real-time PCR.

\section{Discussion}

IDE (insulysin, insulinase, EC 3.4.24.56) is a member of the M16 family of zinc-metalloendopeptidase, which contains a tetrad of conserved residues (H-X-X-E-H-X (76)-E) at its catalytic center (24). This protein is broadly expressed in both insulin-sensitive and insulin-insensitive tissues, and localized mainly in the cytoplasm of cells. However, different forms of this protein can be secreted into the extracellular 
space or associated cell surface $(25,26)$. Until recently, several studies reported various IDE high-affinity substrates, which were polypeptides, 28-51 amino acids in length. A variety of physiological peptides have been shown, in vitro, to be substrates for IDE, including insulin and glucagons (27), the atrial natriuretic factor (28), transforming growth factor $\alpha(29,30)$, atrial natriuretic peptide (31), $\beta$-endorphin and dynorphins (32), amylin (33), and amyloid $\beta$ peptides (34). IDE may also have other biological functions, such as the clearance of the $B$-amyloid precursor protein in the intracellular domain (AICD), which is suggested to regulate the transcriptional activity in the nucleus (35). Furthermore, IDE has been demonstrated to directly interact and enhance the DNA binding of androgen and glucocorticoid receptor fragments in vitro (36). In a recent report, Duckworth et al (37) reported that IDE exists as a complex with the $26 \mathrm{~S}$ proteasome in cells, which is regarded as the principal site of the ubiquitin-dependent intracellular protein. In this study, we characterized the changes in the global gene expression in the livers of $\mathrm{H} 1 / \mathrm{siRNA} \mathrm{insulin}-\mathrm{CMV} / \mathrm{hIDE} \mathrm{Tg}$ mice in response to the reduced bioavailability of insulin. Therefore, the results obtained from the microarray analysis were also due to the effect of overexpressed IDE protein.

Microarray techniques are widely used analytical methods for the detection of changes in the global gene expression in various disease animal models. In particular, this technique has previously been applied to the study of androgen-regulated gene expression in the testis of androgen-binding protein $\mathrm{Tg}$ mice. Three hundred and eighty-one genes were up-regulated and 198 down-regulated in the androgen-deficient animals compared to the control (38). In this study, we analyzed the global gene expression in the livers of $\mathrm{H} 1 / \mathrm{siRNA}_{\text {insulin }}-\mathrm{CMV} /$ hIDE Tg mice, which showed a lower circulating insulin level. The Tg mice used in this study showed quite different diabetic symptoms compared with other diabetic animal models. Until now, most animal models have shown inhibition of the synthesis and signal pathway of insulin due to disruption of its receptor. However, the insulin level in these $\mathrm{Tg}$ mice was significantly decreased, but did not induce damage or disruption to pancreatic tissue. Furthermore, the insulin secreted in the pancreas was rapidly degraded by overexpressed hIDE in the liver $(16,17)$.

Recently, Colombo et al (39) investigated changes in the gene expression in skeletal muscle, liver, fat and pancreatic islets after energy restriction in male Zucker diabetic fatty rats. In our study, the expression of 123 genes was increased, while that of 103 was decreased, in liver tissue related to lipid metabolism. Wilson et al (40) also suggested that 46 genes with lower expression and 8 with higher expression were identified in the kidneys of NOD diabetic mice compared to the NOD nondiabetic control. These genes belong to diverse functional groups, including oxidative phosphorylation, free radical neutralization, channels, pumps, lipid processing, translation and transcription. Furthermore, the gene expression profile was evaluated in the skeletal muscle of type 2 diabetic patients. The transcriptional patterns of 85 genes were shown to be altered in the diabetic patients after withdrawal of insulin treatment compared with those in the nondiabetic control subjects. These altered transcripts were involved in insulin signaling, transcription factors and mitochondrial maintenance (41). In our study, 152 genes were identified as up-regulated and 73 as down-regulated in the livers of H1/ siRNA $_{\text {insulin }}-\mathrm{CMV} / \mathrm{hIDE}$ Tg versus non-Tg mice. A total of 29 up-regulated genes appeared to have 4-fold increases in their expression levels. Of the up-regulated transcripts, as shown in Table III, Egr1, responsible for the transcriptional activity by nucleic acid binding, was most significantly overrepresented (9.66-fold), followed by Saa2, Atf3, Dnajb1 and Tff3. Especially, various transcriptional factors and transporters were significantly increased by insulin regulation in the livers of $\mathrm{Tg}$ mice. Conversely, of the 20 transcripts with the greatest down-regulation (Table IV), those of the cytochrome family coding genes (Cyp17a1 and Cyp2c) were decreased most dramatically, followed by those related to proteolysis, regulation of cell cycle, glycolysis and oxidoreductase activity.

It is very important to confirm the expression ratio of genes from the microarray to fundamentally validate experimental data, which can be performed by quantitative RT-PCR and real-time PCR analysis of selected genes $(38,42)$. In this study, we chose seven of the up- and downregulated genes as judged from the GeneChip data, which were also analyzed by real-time PCR. The fold changes in each gene expression were similar in direction and magnitude between the two techniques (Table V).

Collectively, these results suggest that microarray analysis can identify several functional groups of genes as well as individual genes that respond to sustained reduction of insulin levels in the $\mathrm{Tg}$ liver. Also, these results suggest specific avenues for research toward a better understanding of how insulin regulates diabetes-related diseases.

\section{Acknowledgements}

The authors wish to acknowledge the animal technicians, B.S. Choi, SM, for directing the Animal Facility and Care at the Laboratory Animal Resources Team. This research was supported by a grant from the Scientific Research of the Korean FDA.

\section{References}

1. Mittelman SD, Fu YY, Rebrin K, Steil G and Bergman RN: Indirect effect of insulin to suppress endogenous glucose production is dominant, even with hyperglucagonemia. J Clin Invest 100: 3121-3130, 1997

2. Giacca A, Fisher SJ, Shi ZQ, Gupta R, Lickley HL and Vranic M: Importance of peripheral insulin levels for insulin-induced suppression of glucose production in depancreatized dogs. J Clin Invest 90: 1769-1777, 1992.

3. Lewis GF, Zinman B, Groenewoud Y, Vranic M and Giacca A: Hepatic glucose production is regulated both by direct hepatic and extrahepatic effects of insulin in humans. Diabetes 45 : 454-462, 1996.

4. Lewis GF, Carpentier A, Vranic M and Giacca A: Resistance to insulin's acute direct hepatic effect in suppressing steady-state glucose production in individuals with type 2 diabetes. Diabetes 48: 570-576, 1999.

5. Ferrannini E, Galvan AQ, Gastaldelli A, Camastra S, Sironi AM, Toschi E, Baldi S, Frascerra S, Monzani F, Antonelli A, Nannipieri M, Mari A, Seghieri G and Natali A: Insulin: new roles for an ancient hormone. Eur J Clin Invest 29: 842-852, 1999.

6. Gastaldelli A, Toschi E, Pwttiti M, Frascerra S, Quinones-galvan A, Sironi AM, Natali A and Ferrannini E: Effect of physiological hyperinsulinemia on gluconeogenesis in nondiabetic subjects and in type 2 diabetic patients. Diabetes 50: 1807-1812, 2001. 
7. Boden G, Chen X, Ruiz J, White JV and Rossetti L: Mechanisms of fatty acid-induced inhibition of glucose uptake. J Clin Invest 93: 2438-2446, 1994.

8. Duonf DT, Waltner-Law ME, Sears R, Sealy L and Granner DK: Insulin inhibits hepatocellular glucose production by utilizing liver-enriched transcriptional inhibitory protein to disrupt the association of CREB-binding protein and RNA polymerase II with the phosphoenolpyruvate carboxykinase gene promoter. J Biol Chem 30: 32234-32242, 2002.

9. Hall RK, Yamasaki T, Kucera T, Waltner-Law ME, O'Brien R and Granner DK: Regulation of phosphoenolpyruvate carboxykinase and insulin-like growth factor-binding protein-1 gene expression by insulin. The role of winged helix/forkhead proteins. J Biol Chem 275: 30169-30175, 2000.

10. O'Brien RM and Granner DK: Regulation of gene expression by insulin. Physiol Rev 76: 1109-1161, 1996.

11. Sindelar DK, Chu CA, Neal DW and Cherrington AD: Interaction of equal increments in arterial and portal vein insulin on hepatic glucose production in the dog. Am J Physiol 273: E972-E980, 1997.

12. Lewis GF, Vranic M and Giacca A: Role of free fatty acids and glucagon in the peripheral effect of insulin on glucose production in humans. Am J Physiol 275: E177-E186, 1998.

13. Obici S, Zhang BB, Karkanias G and Rossetti L: Hypothalamic insulin signaling is required for inhibition of glucose production. Nat Med 8: 1376-1382, 2002.

14. Hwang DY, Oh JH, Kim YK, Shim SB, Jee SW, Lee SH, Seo SJ, Song YS, Nam KT, Cho JY, Hwang J, Jang IS and Cho JS: The overexpression of insulin-siRNA and insulin degrading enzyme decrease insulin levels in vitro and in vivo. Lab Anim Res 21: 96-104, 2005.

15. Hwang DY, Seo SJ, Kim KK, Kim YK, Shim SB, Jee SW, Lee SH, Cho JY, Jang IS, Kang BC and Cho JS: The insulin level was significantly decreased in transgenic mice coexpressing the human insulin degrading enzyme and insulinsiRNA. Lab Anim Res 22: 39-47, 2006.

16. Hwang DY, Seo SJ, Kim YK, Kim KK, Shim SB, Jee SW, Lee SH, Sin JS, Cho JY, Kang BC, Jang IS and Cho JS: Significant change in insulin production, glucose tolerance and ER stress signaling in transgenic mice coexpressing insulinsiRNA and human IDE. Int J Mol Med 19: 65-73, 2007.

17. Hasuwa H, Kaseda K, Einarsdottir T and Okabe M: Small interfering RNA and gene silencing in transgenic mice and rats. FEBS Lett 532: 227-230, 2002.

18. Hannon GJ: RNA interference. Nature 418: 244-251, 2002.

19. Hutvagner $\mathrm{G}$ and Zamore PD: RNAi: nature abhors a doublestrand. Curr Opin Genet Dev 12: 225-232, 2002

20. Fire A, Xu S, Montgomery MK, Kostas SA, Driver SE and Mello CC: Potent and specific genetic interference by doublestrand RNA in Caenorhabditis elegans. Nature 391: 806-811, 1998.

21. Brummelkamp TR, Bernards R and Agami R: A system for stable expression of short interfering RNAs in mammalian cells. Science 296: 550-553, 2002.

22. Lee NS, Dohlima T, Bauer G, Li H, Li MJ, Ehsani A, Salvaterra P and Rossi J: Expression of small interfering RNAs targeted against HIV-1 rev transcripts in human cells. Nat Biotechnol 20: 500-505, 2002.

23. Yu JY, Deruiter SL and Turner DL: RNA interference by expression of short-interfering RNAs and hairpin RNAs in mammalian cells. Proc Natl Acad Sci USA 99: 6047-6052, 2002.

24. Duckworth WC, Bennett RG and Hamel FG: Insulin degradation: progress and potential. Endocr Rev 19: 608-624, 1998.

25. Seta KA and Roth RA: Overexpression of insulin degrading enzyme: cellular localization and effects on insulin signaling. Biochem Biophys Res Commun 231: 167-171, 1997.
26. Vekrellis K, Ye Z, Qiu WQ, Walsh D, Hartley D, Chesneau V, Rosner MR and Selkoe DJ: Neurons regulate extracellular levels of amyloid beta-protein via proteolysis by insulindegrading enzyme. J Neurosci 20: 1657-1665, 2000.

27. Kirschmer RJ and Goldberg AL: A high molecular weight metalloendopeptidase from the cytosol of mammalian cells. J Biol Chem 258: 967-976, 1983.

28. Muller D, Baumeister H, Buck F and Richter D: Atrial natriuretic peptide (ANP) is a high-affinity substrate for rat insulin-degrading enzyme. Eur J Biochem 202: 285-292, 1991.

29. Garcia JV, Gehm BD and Rosener MR: An evolutionarily conserved enzyme degrades transforming growth factor-alpha as well as insulin. J Cell Biol 109: 1301-1307, 1989.

30. Gehm BD and Rosner MR: Regulation of insulin, epidermal growth factor, and transforming growth factor-alpha levels by growth factor-degrading enzymes. Endocrinology 128: 1603$16010,1991$.

31. Muller D, Schulze C, Baumeister H, Buck F and Richter D: Rat insulin-degrading enzyme: cleavage pattern of the natriuretic peptide hormones ANP, BNP, and CNP revealed by HPLC and mass spectrometry. Biochemistry 31: 11138-11143, 1992.

32. Safavi A, Miller BC, Cottam L and Hersh LB: Identification of gamma-endorphin-generating enzyme as insulin-degrading enzyme. Biochemistry 35: 14318-14325, 1996

33. Bennett RG, Duckworth WC and Hamel FG: Degradation of amylin by insulin-degrading enzyme. J Biol Chem 275: 36621-36625, 2000.

34. Mukherjee A, Song E, Kihiko-Ehmann M, Goodman JP Jr, Pyrek JS, Esyus S and Hersh LB: Insulysin hydrolyzes amyloid beta peptides to products that are neither neurotoxic nor deposit on amyloid plaques. J Neurosci 20: 8745-8749, 2000.

35. Edbauer D, Willem M, Lammich S, Steiner H and Haass C: Insulin-degrading enzyme rapidly removes the beta-amyloid precursor protein intracellular domain (AICD). J Biol Chem 277: 13389-13393, 2002.

36. Kupfer SR, Wilson EM and French FS: Androgen and glucocorticoid receptors interact with insulin degrading enzyme. J Biol Chem 269: 20622-20628, 1994.

37. Duckworth WC, Bennett RG and Hamel FG: A direct inhibitory effect of insulin on a cytosolic proteolytic complex containing insulin-degradation: progress and multicatalytic proteinase. J Biol Chem 269: 24575-24580, 1994.

38. Petrusz P, Jeyaraj DA and Grossman G: Microarray analysis of androgen-regulated gene expression in testis: the use of the androgen-binding protein (ABP)-transgenic mouse as a model. Reprod Biol Endocrinol 70: 1-14, 2005.

39. Colombo M, Kruhoeffer M, Gregersen S, Agger A, Jeppesen P, Oemtoft T and Hermansen K: Energy restriction prevents the development of type 2 diabetes in Zucker diabetic fatty rats: coordinated patterns of gene expression for energy metabolism in insulin-sensitive tissues and pancreatic islets determined by oligonucleotide microarray analysis. Metabolism 55: 43-52, 2006.

40. Wilson KH, Eckenrode SE, Li QZ, Ruan QG, Yang P, Shi JD, Davoodi-Semiromi A, McIndoe RA, Croker BP and She JX: Microarray analysis of gene expression in the kidneys of new and post-onset diabetic NOD mice. Diabetes 52: 2151-2159, 2003.

41. Sreekumar R, Halvatsiotis P, Schimke JC and Nair KS: Gene expression profile in skeletal muscle of type 2 diabetes and the effect of insulin treatment. Diabetes 51: 1913-1920, 2002.

42. Kume E, Aruga C, Ishizuka Y, Takahashi K, Miwa S, Itoh M, Fujimura H, Toriumi W, Kitamura K and Doi K: Gene expression profiling in streptozotocin treated mouse liver using DNA microarray. Exp Toxicol Pathol 56: 235-244, 2005. 